\title{
Framing of politics (Satirical Shows)
}

\section{AUTHOR}

Dennis Lichtenstein, Cordula Nitsch

\section{KEYWORDS}

framing, politics, political substance, issue frame, strategic frame, news media

\section{BRIEF DESCRIPTION}

This variable examines how politics in general or specific political issues are framed in satirical shows. Some studies that aim to analyze the political substance in the shows differentiate between the framing of politics as an issue and the framing of politics as a strategic game (e.g., Brewer \& Marquart, 2007; Fox et al., 2007). Studies that aim to analyze how satirical shows differ from other media programs in their perspective on specific policy issues use a more differentiated catalogue of issue specific frames or code frame elements (Nitsch \& Lichtenstein, 2019).

FIELD OF APPLICATION/THEORETICAL FOUNDATION The difference between issue and strategy frames has its roots in research on the softening of news (e.g., Lawrence, 2000). Whereas strategy frames are said to attract the audience attention but contribute to political cynicism, issue frames provide substantial political information. Studies that use issue-specific frames are usually interested in satire as an alternative or counter-public media outlet that might challenge mainstream perspectives in politics and the news media.

\section{REFERENCES/COMBINATION WITH OTHER METHODS OF DATA COLLECTION}

Content analyses that examine issue-specific frames compare the content of satirical shows with the content of mainstream news media and other media outlets (Lichtenstein \& Koerth,
2020).

\section{EXAMPLE STUDY}

Nitsch \& Lichtenstein (2019)

INFORMATION ON NITSCH \& LICHTENSTEIN, 2019

Authors: Cordula Nitsch, Dennis Lichtenstein

Research question/research interest: Framing of international crises in satirical shows and whether or not the frame elements parallel official political crisis frames

Object of analysis: Three popular German satirical TV-shows (Die Anstalt, heute show, Neo Magazin Royale)

Timeframe of analysis: 2014-2016

\section{INFORMATION ABOUT VARIABLE}

Variable name/definition: Frame Elemente [frame elements]

Bezogen auf das Unterthema des Beitrags wird das Framing der Krisen codiert. Dabei werden einzelne Frame-Elemente erfasst, die in dem Beitrag vorkommen und ernst gemeint sein können oder kritisiert/dekonstruiert werden.

[In relation to the sub-topic of the story, the framing of the crises is coded. In doing so, individual frame elements (that can be meant seriously or that are criticized/deconstructed) are coded.]

Level of analysis: Beitragsebene

Scale level: Nominal

Reliability: .71

\section{V18 Problemdefinition [PROB]}

Hier wird codiert, vor welchem Wertehintergrund das codierte Unterthema als Problem definiert wird. Es wird also codiert, welcher Wert im Themenkontext als bedroht hervorgehoben wird. 
[Here, the value background against which the coded subtopic is defined as a problem is coded. In other words, it is coded which value is highl- ighted as threatened in the topic context.] see Table 1

\section{Table 1.}

\section{Politische Werte und Rechtsprinzipien}

11 Demokratie

(z.B. das Referendum auf der Krim wird unter militärischem Druck durchgeführt)

12 Frieden

13 Völkerrecht

Rechtsstaatlichkeit

14 z.B. Recht auf Meinungsäußerung, Pressefreiheit, Gleichheit vor dem Gesetz, Minderheitenschutz

Humanität, humanitäre Hilfe in Notsituationen

z.B. Recht auf Leben

16 Solidarität

17 Rationalität, Verantwortlichkeit in Entscheidungsfindung

In Abgrenzung zu Hysterie

Transparenz, Rechtmäßigkeit

In Abgrenzung zu Korruption

19 Anderer Politischer Wert

\section{Staatliche Grundaufgaben und Leitlinien}

21 Sicherheit und Schutz der Bürger

Staatliche Souveränität und Handlungsfähigkeit

22 Kann z.B. durch Überlastung in Flüchtlingskrise gefährdet sein; auch Gewalt über

Staatsgrenzen und Recht auf politische Selbstbestimmung

23 Prinzip der Europäischen Integration und europäischen Zusammenarbeit

Einhaltung von EU-Recht

24 z.B. der Dublin-Regeln (Asyl wird in dem Land beantragt, das Flüchtlinge zuerst betreten)

25 Freizügigkeit im Schengenraum

28 Westbindung 
29 Sozialstaatlichkeit und ökonomische Gleichheit

30 Wirtschaftliche Stabilität und Wohlstand

31 Stabilität der Währung

39 Andere Staatliche Grundaufgabe oder Leitlinie

\section{Weitere Kollektive Prinzipien}

41 Globalisierung

42 Nachhaltigkeit/Zukunft

43 Gleichberechtigung und Gleichheit

z.B. Rechtsgleichheit, Diskriminierungsverbot in der Arbeitswelt

44 Integration in die Gesellschaft

45 Kulturelle Integrität, Schutz des kulturellen Erbes

46 Anti-Rassismus bzw. Anti-Rechtsextremismus

47 Politische Geschlossenheit innerhalb der Nation bzw. EU

(z.B. gefährdet, wenn Schröder mit Putin Geburtstag feiert)

49 Anderes kollektives Prinzip

\section{Individualwerte}

51 Gesundheit

$52 \quad$ Freiheit

53 Identität

54 Persönliche Integrität

z.B. Ehrlichkeit, Verantwortung, Responsivität gegenüber den Bürgern

$55 \quad$ Familie

56 Religiöse Werte

59 Anderer Individualwert

\section{Sonstiges}


99 Anderer Wert

$0 \quad$ Kein Wertebezug hergestellt

\section{V19 Ursachenzuschreibung (URS)}

Hier wird codiert, ob für das Problem eine tieferliegende Ursache ausgemacht wird, die eher strukturell ist und nicht in erster Linie im Fehlverhalten einer Person begründet liegt.

Wird zu einem Unterthema sowohl eine tieferliegende Ursache als auch eine Schuldzuweisung angesprochen, werden beide Variablen (V19 und V20/21) codiert.

[It is coded whether the problem is identified as having a deeper cause, which is more structural and not primarily due to the misconduct of a person.

If both a structural cause and an attribution of blame are addressed for a sub-theme, both variables (V19 and V20/21) are coded.]

see Table 2

\section{Table 2.}

\section{Politische Ursachen}

11 Krieg

12 Geopolitische Interessen

13 Politische Machtinteressen

14 Politische Machtverhältnisse

15 Traditioneller politischer Konflikt

16 Persönlichkeit, persönliche Animositäten zwischen Politikern

17 Juristische Lage, Rechtsprechung

18 Flüchtlingsstrom

19 Andere Politische Ursache

\section{Wirtschaftliche Ursachen}

21 Wirtschaftskrise

In breiter Auslegung von Hungersnot bis Rezession oder Konjunkturschwäche

22 Banken- und/oder Börsencrash

23 Wirtschaftliche Interessen 
24 Wirtschaftliche Zwänge

25 Wirtschaftliche Machtverhältnisse

26 Persönlichkeit, persönliche Animositäten zwischen Vertretern der Wirtschaft

29 Andere Wirtschaftliche Ursache

\section{Gesellschaftlich-kulturelle Ursachen}

31 Historisch

z.B. die Krim ist historisch ein Teil von Russland

32 Kulturell

Traditionen, z.B. auch kulturell verankerte Faulheit der Griechen; Rolle der Frau im

Gesellschaftliche Spaltung

33 z.B. zwischen russisch-sprachigen Minderheiten im Osten und Bevölkerung in Westukraine

34 Persönlichkeit, persönliche Animositäten zwischen Repräsentanten kultureller/gesellschaftlicher Gruppen oder Vereine

39 Andere kulturell-historische Ursache

\section{Sonstiges}

90 Naturkatastrophe oder Unglück

99 Andere Ursache

bitte spezifizieren

$0 \quad$ Keine tiefere Ursache angesprochen

\section{V20 Schuldzuschreibung, Systemzugehörigkeit [SCHUSYS]}

Systemzugehörigkeit des Akteurs, der für das Problem verantwortlich gemacht wird (Akteursliste auf Anfrage bei den Autor*innen erhältlich)

[System affiliation of the actor who is held responsible for the problem (list of actors available from the authors on request)]

\section{V21 Schuldzuschreibung, Nation [SCHUNAT]}

Nationale Zugehörigkeit des Akteurs, der für das Problem verantwortlich gemacht wird (Länderliste auf Anfrage bei den Autor*innen erhältlich)

[National affiliation of the actor who is held responsible for the problem (list of countries available from the authors upon request)] 
V22 Handlungsanweisung bzw. Lösungsidee [LOES]

Hier wird codiert, welche Handlung zur Bearbeitung/Lösung für das Problem bzw. der Krise angesprochen ist. (Lösungsliste auf Anfrage bei den Autor*innen erhältlich)

[It is coded which action is addressed to process/solve the problem or crisis (list of solutions available from the authors on request)]

\section{REFERENCES}

Nitsch, C. \& Lichtenstein, D. (2019). Satirizing international crises. The depiction of the Ukraine, Greek debt and migration crises in political satire. Studies in Communication Science (SComS), 19(1), 85-103. 